\title{
Potrzeby inwestycyjne jednostek samorządu terytorialnego po 2020 r. - czy stać nas na rozwój? Sprawozdanie z konferencji
}

Dnia 25 marca br., z inicjatywy Ministerstwa Inwestycji i Rozwoju, odbyła się konferencja naukowa pt.: „Potrzeby inwestycyjne jednostek samorządu terytorialnego po 2020 r. czy stać nas na rozwój?”, w której uczestniczyli przedstawiciele świata nauki, jednostek samorządowych z kraju, pracownicy MIiR.

Uroczystego otwarcia konferencji dokonał pan Jerzy Kwieciński, Minister Inwestycji i Rozwoju, który przedstawił aktualną sytuację dotyczącą funkcjonowania jednostek samorządu terytorialnego (JST) i perspektywy na 2019 r. Wskaźniki makroekonomiczne w chwili obecnej są w Polsce dobre, 5\% wzrost PKB jest dwukrotnie wyższy niż w Unii Europejskiej, jednak na horyzoncie pojawiają się oznaki spowolnienia rozwoju. W maju br. minie 15 lat naszej obecności w Unii Europejskiej. To okres, w którym w Polsce dokonało się wiele pozytywnych zmian. W 2004 r., w chwili przystępowania Polski do UE, 12 polskich regionów znajdowało się poniżej 50\% średniej unijnej. Obecnie sytuacja jest znacząco lepsza, chociaż nadal występuje duże zróżnicowanie, np. NUTS Warszawski stołeczny osiągnął poziom $150 \%$ średniej unijnej, przewyższając ponad trzykrotnie inne polskie regiony, w tym również Mazowsze.

Pan Minister podkreślił niezwykle istotne znaczenie samorządów i wzrost ich znaczenia, szczególnie poprzez procesy decentralizacji. Zwrócił również uwagę, że na gruncie krajowym niezwykle ważna jest promocja współpracy: samorząd - rząd oraz na potrzebę zmian w Krajowej strategii rozwoju regionalnego; na europejskim: negocjacje i dążenie do jak najgłębszej polityki spójności, zwłaszcza, że Komisja Europejska proponuje znaczące zmniejszenie poziomu wsparcia - z 85 do 70\%, co jest konsekwencją brexitu - Wielka Brytania miała 10\% wkład w budżet UE. W tej sytuacji niezwykle pomocny może okazać się program wsparcia dla Polski z Funduszy Norweskich. Kończąc swoje wystąpienie, prelegent przedstawił aktualne priorytety Unii Europejskiej, do których m.in. należą: bezpieczeństwo zewnętrzne, ochrona granic, wzrost innowacyjności, polityka klimatyczna.

Kolejnym punktem spotkania było wystąpienie pana profesora Michała Bitnera z Uniwersytetu Warszawskiego, który przedstawił wyniki raportu „Koszty funkcjonowania inwestycji JST sfinansowanych z funduszy UE”1. Głównym celem była odpowiedź na pytanie zawarte $\mathrm{w}$ tytule konferencji. Infrastruktura powstała w Polsce od momentu wstąpienia do UE i sfinansowana z funduszy europejskich jest niezwykle istotna dla rozwoju kraju, przyczynia się do zmniejszenia dysproporcji pomiędzy obszarami zurbanizowanymi a wiejskimi, poprawy jakości życia mieszkańców, podnosi atrakcyjność inwestycyjną danego regionu, a to przekłada się na osiąganie przewagi konkurencyjnej na poziomie lokalnym,

\footnotetext{
${ }^{1}$ Raport „,Koszty funkcjonowania inwestycji JST sfinansowanych z funduszy UE”, przygotowany przez zespół w składzie: dr hab. Michał Bitner, dr hab. Andrzej Gałązka, dr Jacek Sierak, na zlecenie Krajowego Obserwatorium Terytorialnego, działającego w Ministerstwie Inwestycïi Rozwoju.
} 
krajowym, a nawet międzynarodowym. Nowoczesna infrastruktura przynosi określone zyski, ale również generuje wysokie koszty związane z jej utrzymaniem i modernizacją które obciążają budżety samorządów, a w skrajnych przypadkach mogą zachwiać równowagę finansową danej jednostki terytorialnej. W omawianym Raporcie oszacowano koszty inwestycji infrastrukturalnych $\mathrm{w}$ pięciu dziedzinach: zbiorowego zaopatrzenia w wodę i odprowadzania ścieków (wodociągi i kanalizacja), oświaty (np. szkoły, przedszkola, ośrodki szkolne i wychowawcze, placówki doskonalenia nauczycieli), opieki społecznej (np. ośrodki pomocy społecznej, domy pomocy społecznej, placówki opiekuńczo-wychowawcze), kultury (np. muzea, teatry, ośrodki kultury, biblioteki), ochrony zdrowia (np. samorządowe samodzielne publiczne zakłady opieki zdrowotnej SPZOZ). Do wydatków związanych z funkcjonowaniem inwestycji zaliczono koszty: materiałów eksploatacyjnych, energii, usług obcych (w tym remontów), wynagrodzeń i pochodnych, podatki i opłaty, pozostałe.

W badaniach wykorzystano dane pochodzące ze sprawozdań finansowych oraz dane bezpośrednio dotyczące kosztów funkcjonowania zrealizowanych inwestycji uzyskane w wyniku badań ankietowych ${ }^{2}$. Wyniki uzyskane ze sprawozdań finansowych pozwalają stwierdzić, że największe koszty generują wynagrodzenia (szkoły 90\%, przedszkola 84\%, ośrodki kultury, biblioteki, archiwa, DPS ok. 75\%, teatry, filharmonie, muzea ok. 70\%, ochrona zdrowia ok. 50\%), a w dalszej kolejności energia i materiały eksploatacyjne (inwestycje wodno-kanalizacyjne - ok. 25\%, placówki opiekuńczo-wychowawcze 15\%, przedszkola 10,5\%, muzea 10\%, szkoły 7\%). Wyniki badań pokazuja, że wzrost wartości majątku trwałego inwestycji pociąga za sobą w miarę proporcjonalny koszt funkcjonowania danej jednostki. Z analizy badań ankietowych wynika, że największe roczne koszty funkcjonowania generują inwestycje w zakresie ochrony zdrowia i opieki społecznej, odpowiednio $40 \%$ i 33,5\%, a największy udział w kosztach mają wynagrodzenia oraz materiały i energia.

Po wystąpieniu prof. M. Bitnera miała miejsce dyskusja panelowa, prowadzona przez redaktora Radosława Brzózkę, w której uczestniczyli państwo: Jakub Chełstowski, Marszałek Województwa Śląskiego, Jarosław Komża ze Związku Powiatów Polskich, Jacek Pauli, Burmistrz Gminy Skaryszewy, Marek Wiewióra z Departamentu Finansów Samorządu Terytorialnego Ministerstwa Finansów i Monika Stanny z Polskiej Akademii Nauk.

W drugiej części konferencji pan dr Jacek Sierak, reprezentujący Szkołę Główną Handlowa, przedstawił wyniki raportu pt.: „Potrzeby inwestycyjne jednostek samorządu terytorialnego do 2020 r. i po 2020 r. w zakresie wybranych rodzajów infrastruktury oraz możliwości ich finansowania funduszami unijnymi”3.

Podmiotem badania były jednostki samorządu terytorialnego, miasta na prawach powiatu, pozostałe gminy (miejskie, wiejskie, miejsko-wiejskie), a celem - oszacowanie

\footnotetext{
2 Nie przytaczam szczegółowych opisów i wyników, ponieważ Raport jest dostępny pod adresem: www.funduszeeuropejskie.gov.pl/

3 Raport „Potrzeby inwestycyjne jednostek samorządu terytorialnego do 2020 r. i po 2020 r. w zakresie wybranych rodzajów infrastruktury oraz możliwości ich finansowania funduszami unijnymi”, przygotowany przez zespół w składzie: dr Jacek Sierak - kierownik badania, dr hab. Michał Bitner, dr hab. Andrzej Gałązka, dr hab. Jacek Brdulak, dr Ewelina Florczak, dr hab. Zbigniew Grzymała, mgr Magdalena Dziczek, mgr Cezary Krysiuk, na zlecenie Krajowego Obserwatorium Terytorialnego, działającego w Ministerstwie Inwestycji i Rozwoju (www.funduszeeuropejskie.gov.pl).
} 
potrzeb inwestycyjnych gmin oraz ocena możliwości zaspokojenia tych potrzeb w aspekcie finansowym. W rozważaniach wzięto pod uwagę: potrzeby inwestycyjne jednostek samorządu terytorialnego w zakresie wodociągów i kanalizacji, oczyszczalni ścieków, gospodarki odpadami komunalnymi i dróg wojewódzkich. Wyniki badań wykazały, że szacunkowe potrzeby inwestycyjne (ilościowe i jakościowe) w latach 2018-2027 wyniosą ponad 168 mld zł, w tym: wodociągi i kanalizacja - 93 mld zł, gospodarka odpadami - 24 mld zł, drogi wojewódzkie - 51 mld zł (w tym: nowe inwestycje drogowe 27 mld zł, modernizacja istniejącej sieci-24 mld zł). W odniesieniu do wodociągów i kanalizacji udział poszczególnych potrzeb wygląda następująco: budowa nowych sieci wodociągowych $16 \mathrm{mld}$ zł (17\% całości potrzeb), budowa nowych sieci kanalizacyjnych ok. 64 mld zł (68,5\%), modernizacja i odtworzenie sieci wodociągowej ponad $7 \mathrm{mld}$ zł (7,7\%), modernizacja i odtworzenie sieci kanalizacyjnej 6 mld zł (6,8\%). Rozwój inwestycji w zakresie wodociągów i kanalizacji następował w całym kraju, dysproporcje w długości tych sieci są zauważalne zarówno w skali kraju, jak i poszczególnych województw (wyraźne opóźnienie rozwoju systemów kanalizacyjnych w porównaniu z wodociągowymi), nowe inwestycje powstawały głównie w Polsce wschodniej i centralnej, a szybszy rozwój następował w strefach podmiejskich. Łączne potrzeby inwestycyjne polskich gmin w zakresie budowy i modernizacji sieci wodociągowych i kanalizacyjnych oszacowano na 270 tys. $\mathrm{km}$.

Szacowane 24 mld zł na potrzeby inwestycji w zakresie gospodarki odpadami powinny być, zdaniem autorów Raportu, przeznaczone na realizację projektów związanych z budową i modernizacją instalacji ukierunkowanych na odzysk materiałów, recykling, biogazownie.

Utrzymanie, rozwój, modernizacja inwestycji w wyżej wymienionych dziedzinach gospodarki nie będzie mogła być zrealizowana na planowanym poziomie bez znaczących dopłat z UE.

Po prezentacji Raportu odbyła się kolejna dyskusja panelowa, w której udział wzięli państwo: Christopher Todd, Dyrektor Wydziału ds. Polski DG REGIO, Komisja Europejska, Lucjusz Nadbereżny, Prezydent Stalowej Woli, Andrzej Pietrasik, Burmistrz Miasta Płońska, Tomasz Podkański, Zastępca Dyrektora Biura Związku Miast Polskich, Agnieszka Kopańska z Uniwersytetu Warszawskiego. Paneliści wymieniali się własnymi doświadczeniami, wynikami prowadzonych badań, analizowali wnioski z prezentowanych Raportów. Za najważniejsze wyzwanie uznano prowadzenie polityki spójności zarówno na poziomie krajowym, jak i europejskim, bowiem tylko taka polityka może zapewnić zrównoważony rozwój, pozwalający na wyrównywanie różnic regionom biedniejszym i zaniedbanym. Moderatorem dyskusji, podobnie jak w części pierwszej, był redaktor Radosław Brzózka, a jego merytoryczne przygotowanie do tematu zapewniło interesującą i utrzymaną w ryzach czasowych dyskusję.

Podsumowania konferencji dokonał pan Robert Dzierzgwa, Dyrektor Departamentu Strategii Rozwoju Ministerstwa Inwestycji i Rozwoju. 